\title{
GILKA MACHADO, POETA MODERNA
}

\author{
GILKA MACHADO, A MODERN POET
}

\author{
Anélia Montechiari PIETRANI ${ }^{1}$
}

\begin{abstract}
Resumo: Tomando por relevo as relações político-textuais e político-contextuais dos estudos literários, este artigo tem por objetivo interpretar poemas de Gilka Machado (1893-1980), cuja produção teve início naquele momento nomeado por alguns críticos historiográficos como pré-modernismo, um período de transição que reúne tendências conservadoras e renovadoras no início do século XX brasileiro. A poesia de Gilka Machado estabelece diálogos com essas tendências literárias, mas constrói uma voz poética muito própria, marcada por intensa carga de erotização e por reflexões sobre o papel social e cultural das mulheres - temáticas já amplamente estudadas pela fortuna crítica da autora, que podem ser bastante enriquecidas quando conjugadas à abordagem sobre a consciência poética que ela expressa em sua poesia. Exemplo significativo dessa comunhão de aspectos se encontra no poema "Lépida e leve", publicado em Meu glorioso pecado (1928), cuja leitura interpretativa dos traços imagéticos, estilísticos e vanguardistas aponta-o em direção à poesia moderna de Gilka Machado em seu "momento futurista", no sentido estudado por Marjorie Perloff a partir do termo cunhado por Renato Poggioli.
\end{abstract}

Palavras-chave: Gilka Machado. Poesia moderna brasileira. Crítica literária feminista. Consciência poética.

\begin{abstract}
Taking into account the political-textual and political-contextual relations of literary studies, this paper aims to read poems written by Gilka Machado (1893-1980), whose work began at that moment named by some historiographical scholars as premodernism, a period of conservative and renewing tendencies in the early Brazilian twentieth century. Gilka Machado's poetry dialogues with these literary tendencies, but constructs a personal poetic voice, marked by intense eroticizing load, and by discussions about the social and cultural role of women, which had been widely studied by her critical fortune. These themes can be enriched when linked to her poetic consciousness. Conjugating these quoted aspects and considering especially the imagistic, stylistic and avant-garde points in the interpretation. Her poem entitled "Lépida e leve", published in Meu glorioso pecado (1928), is an example of Gilka Machado's modern poetry in her "futuristic moment", in the sense studied by Marjorie Perloff, from the term coined by Renato Poggioli.
\end{abstract}

Keywords: Gilka Machado. Modern Brazilian poetry. Feminist literary criticism. Poetic consciousness.

\section{Uma palavra inicial}

Gilka Machado (1893-1980) publica Cristais partidos em 1915, em um momento difícil de precisar literariamente, o do pós-romantismo de 1880 a 1922, segundo Antonio Candido em Literatura e sociedade, ou o do pré-modernismo das duas primeiras décadas do século $\mathrm{XX}$, na expressão cunhada por Tristão de Ataíde (pseudônimo de Alceu de Amoroso Lima). Acerca desse período da literatura na Belle Époque brasileira, em que vários “ismos" são mais

\footnotetext{
${ }^{1}$ Professora Associada de Literatura Brasileira - Programa de Pós-Graduação em Letras Vernáculas - UFRJ; Doutorado em Letras pela Universidade Federal Fluminense; e-mail: aneliapietrani@letras.ufrj.br
} 
simultâneos do que sucessivos - parnasianismo, simbolismo, impressionismo, decadentismo, penumbrismo -, talvez só possamos dizer que nele convivem tendências conservadoras e renovadoras.

Sob esse aspecto, o título que a poeta escolhe para seu primeiro livro assume valor bastante significativo: a geometria da organização sólida do cristal, desfazendo-se em partes, se faz em outras novas partes. Com uma poética de cristais também partidos, Gilka Machado estabelece diálogos com diferentes estilos literários, mas constrói uma voz poética muito própria, aproximando-se, inclusive, do Modernismo. Como assinalou com acerto Manuel Bandeira em Apresentação da poesia brasileira, a poesia de Gilka é marcada pelo "forte temperamento afirmado numa série de livros" (BANDEIRA, 1957, p. 107), ao que ele acrescenta que, no conjunto da poesia na véspera do modernismo brasileiro, "nessa música de timbres mais ou menos suaves, discrepavam [...] as vozes diferentes, tumultuárias, irredutíveis aos quadros classificadores de uma Gilka Machado" (BANDEIRA, 1957, p. 127).

Em Estados de alma, segundo livro da poeta carioca, lançado em 1917, o corpo é quem fala, confirmando a intensidade erótica de sua poesia, largamente explorada por sua fortuna crítica. Ela também atravessará o tempestuoso modernismo da década de 20, com toda a tempestuosidade de sua voz: em 1922, mesmo ano de realização da Semana de Arte Moderna de São Paulo, publica Mulher nua, título ousado para a época, especialmente para uma poetamulher. No final da chamada fase heroica do modernismo brasileiro, em 1928, vem à luz Meu glorioso pecado, título também ousado, por conta da conjugação paradoxal e irônica entre "pecado" e "glória”. Dez anos depois, Sublimação mantém o paradoxo e a ironia emblemáticas da voz gilkiana: sua opção "pouco sublime" passa a ser o verso livre rimado e os temas de conteúdo social ligados aos problemas do povo - e quem ousará dizer que esse livro seja menos sublime? Em Velha poesia, de 1965, que marca o cinquentenário de publicação de seu primeiro livro, os cristais partidos são os das reminiscências e da reflexão sobre a velhice e a morte. Gilka encerra seu último livro com o poema sobre o filho morto, perguntando: "por que ele e não eu?!"2

Para este artigo, tomaremos como palavra inaugural de sua obra a própria Gilka Machado em texto autobiográfico de 1978, possivelmente suas últimas palavras registradas em livro. Nesse depoimento, a poeta se refere a um momento bem anterior a tudo isso, mais precisamente ao ano de 1906, quando ainda contava 13 anos de idade:

\footnotetext{
2 Provavelmente, o poema "Meu menino" deve ter sido adicionado ao conjunto de poemas de Velha poesia na publicação de suas Poesias completas de 1978, já que o filho Hélios faleceu em 1976, dois anos antes de ela morrer, em 1980, na cidade em que nasceu, Rio de Janeiro.
}

Revista Graphos, vol. 21, n² 2, 2019 | UFPB/PPGL | ISSN 1516-1536 


\begin{abstract}
Estreei nas letras, vencendo um concurso literário num jornal, A Imprensa, dirigida por José do Patrocínio Filho. Logo depois, um crítico famoso escrevia que aqueles poemas deveriam ter sido laborados por uma matrona imoral. Quase criança, comunicativa, indiscreta e falaz, saindo de mim mesma, contando meus prazeres e tristezas, expondo os meus defeitos e qualidades, eu pensava apenas em dar novas expressões à poesia. Aquela primeira crítica (por que negar) surpreendeu-me, machucou-me e manchou o meu destino. Em compensação, imunizou-me contra a malícia dos adjetivos.

Havia no meu ser uma torrente que era impossível represar: os versos fluíam, as estrofes cascateavam... e continuei, ritmando minha verdade, então com mais veemência (MACHADO, 1978, p. IX-X).
\end{abstract}

Dois aspectos chamam a atenção nesse trecho: Gilka diz que "pensava apenas em dar novas expressões à poesia", ao que acrescenta que havia no seu ser "uma torrente que era impossível represar: os versos fluíam, as estrofes cascateavam...” Para ela, esse era o ritmo de sua verdade poética. De fato, a leitura da obra daquela que Carlos Drummond de Andrade considerou "a primeira mulher nua da poesia brasileira"3 (ANDRADE, 1980, p. 7) nos permite observar que o novo modo de expressão que ela pensa e realiza poeticamente está intrinsecamente associado ao sentimento do desejo de fazer poesia e fazer-se em poesia. Como a própria palavra de Gilka Machado denuncia, existe um "mais" nesse desejo erótico de sua poesia.

O erotismo em seus textos é mais do que a descrição do corpo em seu "glorioso pecado"; é mais do que o enlevo do encontro (ou desencontro) sexual amoroso; é mais do que a riqueza do efeito sinestésico numa gama de sensações visuais, cromáticas e sonoras, pelo destaque que a poeta dá a um sentido até então pouco explorado em poesia - o tato; é bem mais do que suas “ousadias, perfeitamente válidas e pioneiras" (PY, 1978, p. XXVII), no dizer de Fernando Py, em prefácio às suas Poesias completas de 1978. O erotismo na poesia de Gilka exige uma compreensão além ainda do que afirma Domingos Carvalho da Silva, em Vozes femininas da poesia brasileira, segundo o qual "o êxito de Gilka Machado [...] deve-se principalmente aos temas sensuais, não porque fossem novos, mas por terem sido enfrentados, pela primeira vez, não por um poeta, mas por uma poetisa” (SILVA, 1959, p. 25), complementando, numa tentativa de rebaixar a qualidade de seus textos, que, "no culto da arte defendida por Gilka Machado, as emoções humanas sobrepõem-se às de ordem estética" (SILVA, 1959, p. 26). Sobre o viés erótico como elemento central na construção poética de Gilka Machado também

\footnotetext{
${ }^{3} \mathrm{O}$ pioneirismo de Gilka Machado nesse aspecto é discutível e ainda carece de estudo aprofundado. A título de exemplificação, destaquemos ao leitor curioso dois poemas publicados anteriormente, que merecem entrar nos compêndios da literatura erótica escrita por mulheres, ainda que, obviamente, tenham recebido por parte das autoras uma abordagem erótica diferente da de Gilka: "O baile", de Narcisa Amália em Nebulosas (1872), e "Versos ligeiros", de Auta de Souza em Horto (1900).
} 
escreveu Nelly Novaes Coelho. Em seu Dicionário crítico de escritoras brasileiras (17112001), ela nos alerta que devemos sim pensar que é esta uma poesia escrita por uma mulher:

Desafiando os preconceitos, Gilka Machado ousa expressar, em poesia, a paixão dos sentidos, a volúpia do amor carnal e o dramático choque entre o corpo e a alma. Choque provocado pelo Cristianismo, ao lançar o anátema ao prazer sexual, à fruição da carne. Gilka Machado obviamente chocou a sociedade do tempo com seu ousado desvendar de paixões ou sensações proibidas à mulher (COELHO, 2002, p. 229).

A poesia de Gilka Machado é tudo isso de que fala Nelly Novaes Coelho, assim como é um tanto do que falam os demais críticos homens citados, mas é também - e principalmente o arroubo erótico no próprio fazer poético, o que nos permite descartar a hierarquia entre emoções humanas e estéticas estabelecida por Domingos Carvalho da Silva a respeito de sua poesia. Ambas são forças presentes em seus textos que, sem jamais se anularem, são complementares a partir do que compreende Angélica Soares (1999) em estudos publicados no livro A paixão emancipatória acerca da "irresistível atração" que a poesia de Gilka estabelece entre "consciência literária do erotismo e consciência erótica do literário" (SOARES, 1999, p. 19).

Tomando o mote que nos deixou Angélica Soares e expandindo-o para a reflexão sobre a modernidade da poesia gilkiana, desenvolveremos a ideia de que é na conjugação do dizer erótico e do fazer poético em permanente e reflexiva poiesis que podemos aproximar Gilka Machado bem mais do modernismo do que das escolas literárias anteriores, ainda que possa com elas dialogar. Essa linha de reflexão sobre a poesia de Gilka, no que diz respeito à compreensão da construção de sua poética moderna - e mesmo próxima às tendências de vanguarda, como veremos -, se afina com o pensamento de Paul Valéry no texto "Questões de poesia”, de 1935, que assim sintetizou a situação da produção poética no período entre o fim do século XIX e início do século XX:

Há cerca de quarenta e cinco anos, vi a poesia sofrer muitas agressões, ser submetida a experiências de uma extrema diversidade, experimentar caminhos totalmente desconhecidos, voltar às vezes a certas tradições; participar, em suma, das bruscas flutuações e do regime de novidade frequente que parecem ser características do mundo atual. A riqueza e a fragilidade das combinações, a instabilidade dos gostos e as transmutações rápidas de valores; finalmente, a crença nos extremos e o desaparecimento do durável são traços dessa época, que seriam ainda bem mais sensíveis se não respondessem com muita exatidão à nossa própria sensibilidade, que se torna cada vez mais obtusa.

Nessa última metade do século, uma sucessão de fórmulas ou de modelos poéticos se pronunciaram, desde o tipo estrito e facilmente definível do Parnaso até as produções mais corrompidas e as tentativas realmente mais livres. É conveniente, e importante, juntar a esse conjunto de invenções certas retomadas frequentemente muito felizes: 
empréstimos feitos aos séculos XVI, XVII e XVIII de formas puras ou eruditas, cuja elegância é, talvez, imprescritível (VALÉRY, 1991, p. 177).

Convém insistir no fato de que às invenções da poesia de Gilka Machado se incorporam retomadas e renovações. Passemos, portanto, à leitura de alguns poemas renovadores e inovadores, recolhidos de sua obra poética como exemplos de denúncia social, de natureza erótica e de consciência poética.

\title{
Poesia de denúncia social
}

O exemplo inicial ${ }^{4}$ de nossa leitura da poética de Gilka Machado será "uma forma pura ou erudita", no dizer de Valéry: o soneto "Ser mulher...", penúltimo poema que integra seu primeiro livro, Cristais partidos:

\author{
Ser mulher... \\ Ser mulher, vir à luz trazendo a alma talhada \\ para os gozos da vida: a liberdade e o amor; \\ tentar da glória a etérea e altívola escalada, \\ na eterna aspiração de um sonho superior... \\ Ser mulher, desejar outra alma pura e alada \\ para poder, com ela, o infinito transpor; \\ sentir a vida triste, insípida, isolada, \\ buscar um companheiro e encontrar um Senhor... \\ Ser mulher, calcular todo o infinito curto \\ para a larga expansão do desejado surto, \\ no ascenso espiritual aos perfeitos ideais... \\ Ser mulher, e, oh! atroz, tantálica tristeza! \\ ficar na vida qual uma águia inerte, presa \\ nos pesados grilhões dos preceitos sociais! (MACHADO, 1978, p. 56)
}

"Ser mulher..." conduz o leitor, inicialmente, a uma atmosfera de sonho, desejo, sublimação e ascensão. Porém, a ruptura nesse quadro de sugestões se estabelece exatamente quando a voz lírica destaca a oposição entre o desejo de "ser mulher" e o "ficar na vida". A catábase à vida se acentua no verso "buscar um companheiro e encontrar um Senhor", que nos convoca à igualdade que as mulheres buscam, à igualdade de direitos e afetos, à igualdade e fraternidade do pão partilhado, sentido que, aliás, se encontra na própria raiz etimológica da

\footnotetext{
${ }^{4}$ Considerando que as publicações dos livros de Gilka Machado apresentam divergência quanto à estrofação, pontuação, grafia e ao emprego de certos vocábulos, substituídos ou omitidos em diferentes edições, optamos por transcrever neste artigo os poemas de Poesias completas, de 1978, última antologia que Gilka pôde supervisionar. Revista Graphos, vol. 21, $\mathrm{n}^{\circ}$ 2, 2019 | UFPB/PPGL | ISSN 1516-1536
} 
palavra companheiro (cum-panis). Essa sentença nos remete também ao encontro, ou ao desencontro, da submissão da mulher ao homem, da subserviência a um senhor.

Se a palavra "senhor" não quebra a sonoridade da rima com "amor", "superior" e "transpor", torna dissonante o leitmotiv do canto sublime, elevado e supostamente "puro" do soneto em versos alexandrinos, instaurando, nos tercetos, a tensão não mais da lírica, mas da tragédia anunciada: a ideia paradoxal de um "infinito curto" se soma a uma linguagem áspera, marcada pelos encontros consonantais e pela aliteração dos fonemas oclusivos /t/ e /p/: "atroz, tantálica tristeza", "presa nos pesados grilhões dos preceitos sociais", que, literalmente, pesam o poema e prendem a voz poética. Se obstáculos existem nos recursos expressionais fonéticos do poema, obstáculos também aparecem na representação imagética de repressão do desejo, de fechamento e prisão, especialmente com as figuras de Tântalo, da águia inerte e dos grilhões, ideia que ela também desenvolve em "Ânsia de azul”, um dos primeiros poemas do livro Cristais partidos:

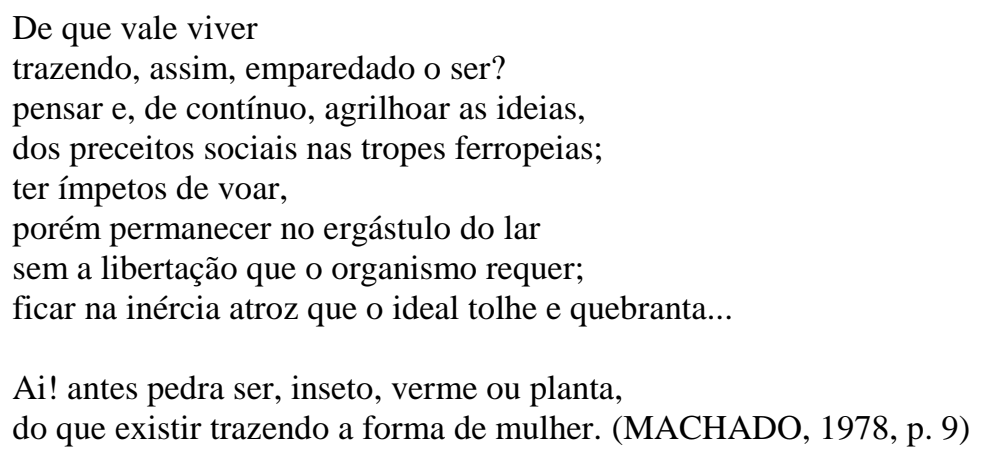

A “águia inerte" conduz ainda o leitor a uma espécie de memória de leitura. A imagem com que Gilka encerra seu poema recorda o albatroz do poema homônimo de Charles Baudelaire, que, apreendido pelos homens do navio e "exilado no chão" (BAUDELAIRE, 1985, p. 111), é o próprio poeta. No poema de Gilka, a águia também está “exilada no chão”, só que como uma mulher presa a um senhor e reprimida pela sociedade, longe da liberdade do voo, do desejo e da palavra.

Embora em "Ser mulher..." Gilka Machado não faça diretamente essa associação, são muitos os seus poemas em que céu se associa à liberdade e à poesia, em que o desejo do fazer poético é a liberdade que a palavra encontra no céu da natureza poética. Convém lembrar a etimologia de desejo - desiderium, que tem em seu radical "sidera", "astro". O locus eroticus da poesia gilkiana é o mesmo locus poeticus livre que a palavra em poesia dá à mulher, já que a sociedade lhe nega o mesmo anseio, o mesmo desejo, a mesma liberdade - a liberdade de 
falar por si mesma, a liberdade de ser agente de sua poesia e narrativa, como tema e como autora.

\section{Natureza erótica da poesia}

É o que podemos observar, por exemplo, nos textos de Gilka em que a natureza aparece como elemento-chave na abordagem temática. Em geral, a natureza não está presente em seus poemas apenas como cenário; ela é partícipe dos enleios eróticos, que talvez sejam os momentos poéticos em que ela melhor lê a larga tradição da natureza na literatura, desde o idílio bucólico virgiliano, o locus amoenus árcade, o locus horrendus romântico como espelho das angústias do poeta, e inaugura na literatura brasileira não apenas a expressividade erótica nos versos escritos por uma mulher, mas o locus eroticus, ao reunir prazer, amor e subjetividade dramática, conforme argumento de Darlene Sadlier (2013) em "O locus eroticus na poesia de Gilka Machado".

Convém insistir sobre esse aspecto, embora já suficientemente comentado no artigo acima referido, porque ele abrirá caminho para refletirmos sobre a relação entre natureza, erotismo e fazer poético, entre locus eroticus - segundo expressão de Sadlier - e o que nomeamos locus poeticus na obra de Gilka Machado. Para melhor discutirmos essa questão, seguem transcritos dois sonetos: um de Estados de alma (de 1917):

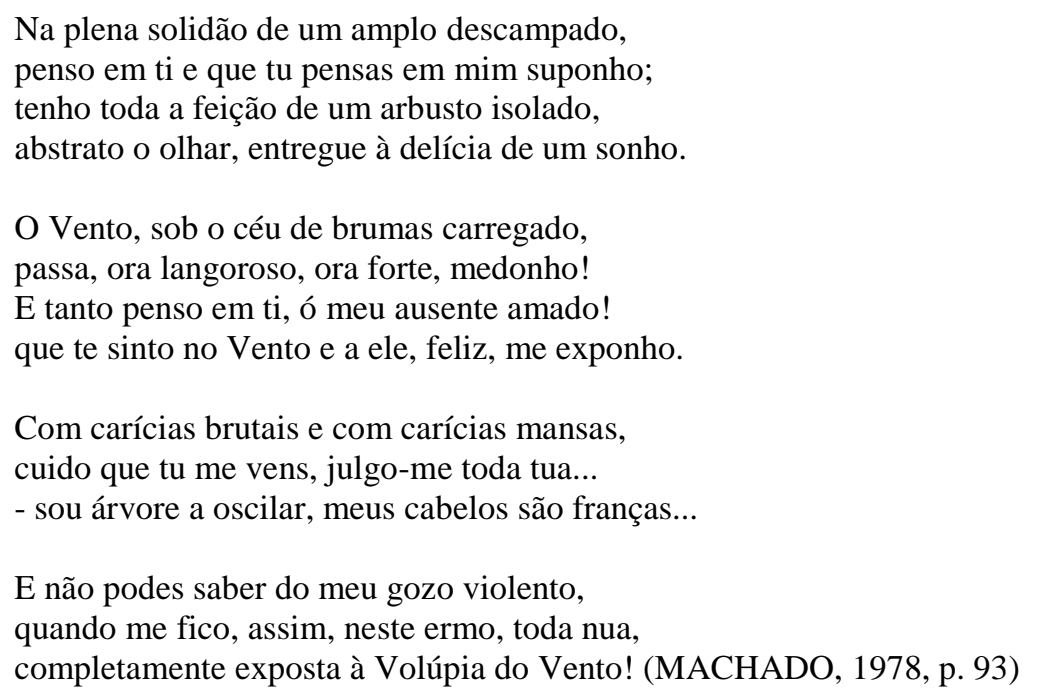

e outro de Meu glorioso pecado (de 1928): 


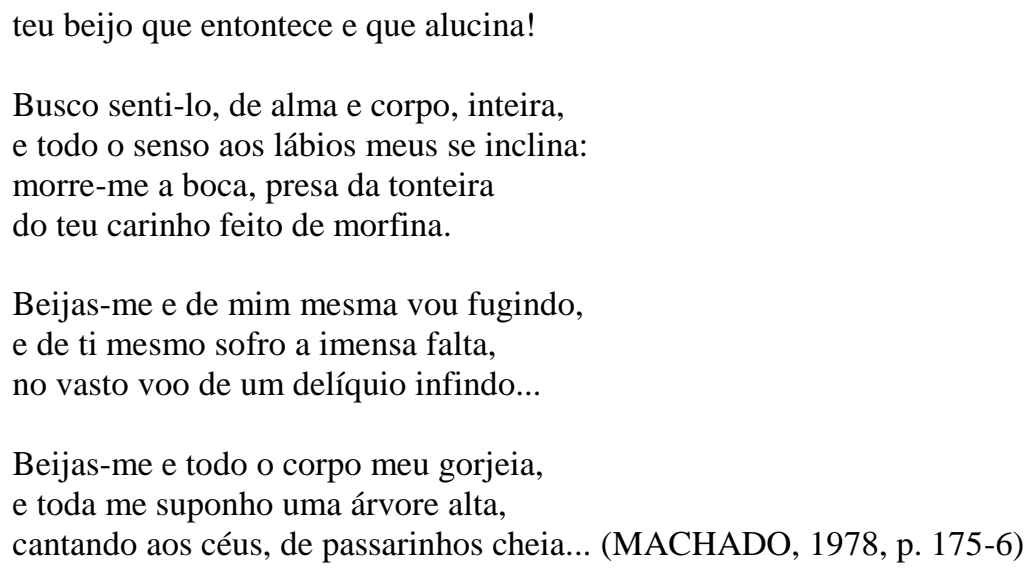

Nos dois sonetos, a fruição amorosa está ligada à liberdade: são recorrentes as imagens de vento, pássaros, céus, árvore alta, voo. A situação dramática em nenhum momento é atenuada; antes, se acentua. Observemos que o ser amado não está presente na cena poética do primeiro poema: "ó meu amado ausente", "cuido que tu me vens". Essa ausência física remete a um aspecto importante a se destacar nesse primeiro soneto: o homem até pode ser o inspirador do desejo, mas é a mulher que realiza sozinha o ato, acentuado pelo toque sensual e sexual da natureza em forma de vento, que aparece marcado e sentido no corpo do poema pela aliteração do /v/: "E não podes saber do meu gozo violento,/ quando me fico assim neste ermo, toda nua,/ completamente exposta à Volúpia do Vento!" Embora ainda sob o indício da repressão, parecendo ter que ocultar o ato ("não podes saber”) que só a palavra poética pode dizer, a masturbação feminina junto à natureza até pode ser tratada por Gilka como seu "glorioso pecado", mas não como o mal. A mulher, em sua poesia, é pecadora, no entanto é conquistadora, vitoriosa, gloriosa, agente de seu próprio gozo.

O segundo soneto dá encaminhamento a essas reflexões: também não há aqui a visão de corpo e de carne como mal. Embora, como no soneto anterior, o outro também não esteja presente ("e de ti mesmo sofro a imensa falta"), o beijo que se repete a cada estrofe, com a anáfora "beijas-me", a aliteração do fonema /b/ em palavras constelarmente distribuídas e repetidas no poema (boca, beijo, busco) e a assonância em /o/, ora aberto, ora fechado, intensificam o ato e desejo amorosos, na união de corpo e alma representada exatamente pela natureza em que o eu poético se transmuta panteisticamente: seu corpo é a própria árvore que aponta para o alto, que canta livre aos céus dos pássaros e como os pássaros; seu corpo é conjugado à alma exatamente pela experiência simultânea do desejo do corpo e do canto, de que a imagem da árvore é bem elucidativa. Ela está presa à terra, mas é alta, aponta para o alto e, por isso, gorjeia (o pássaro? a árvore? o eu poético?) livre no céu da copa da árvore e dos pássaros. É nesse espaço da natureza enlevada (e elevada) que se realiza o desejo, em que o 
gozo do amor e o gozo do canto (é bom insistir nesse enlace) se encontram; em que, portanto, se mantêm unidos corpo e alma, contradizendo, de certa forma, a visão machista segundo a qual a mulher é mãe, educadora, o espírito e a alma da família, completamente sem corpo.

Nesses dois poemas, e em muitos outros, a mulher tem a liberdade de ser amada e amante, seu corpo é seu canto (seu canto é seu corpo), ela é sujeito do ato amoroso e cantora de seu arroubo erótico, tomando parte inteira (sem qualquer paradoxo) de seu canto e seu gozo. Lembrando das palavras do depoimento de Gilka, citado no início deste artigo, sobre a torrente que lhe era impossível represar, exatamente porque os versos fluíam e as estrofes cascateavam, podemos afirmar que, em Gilka Machado, o locus eroticus é o próprio locus poeticus, que constituem - juntos - o espaço da liberdade conquistado pela mulher-ave-árvore-poeta: o erotismo de seu canto está no corpo erotizado da palavra.

\section{Metalíngua, ou meta a língua na poesia}

Um dos melhores exemplos de canto erótico de Gilka Machado é o poema sem título, integrante do livro Meu glorioso pecado, que se inicia pelo verso "Lépida e leve":

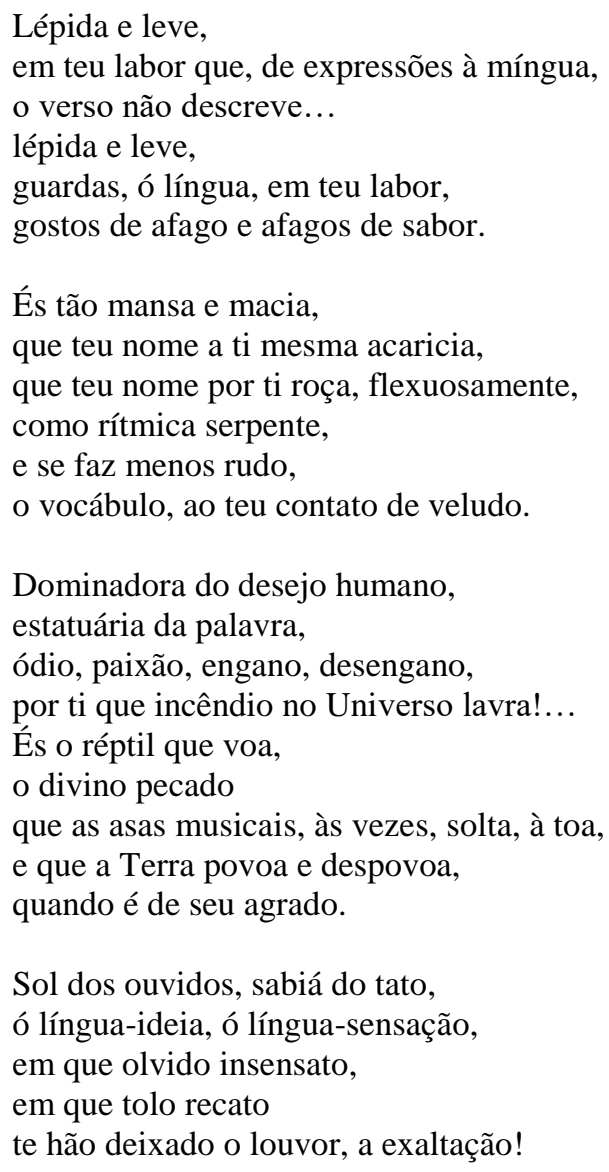


- Tu que irradiar pudeste os mais formosos poemas!

- Tu que orquestrar soubeste as carícias supremas!

Dás corpo ao beijo, dás antera à boca,

és o tateio de alucinação,

és o elastério da alma... Ó minha louca

língua, do meu Amor penetra a boca,

passa-lhe em todo senso tua mão,

enche-o de mim, deixa-me oca...

- tenho certeza, minha louca,

de lhe dar a morder em ti meu coração!...

Língua do meu Amor velosa e doce,

que me convences de que sou frase,

que me contornas, que me vestes quase,

como se o corpo meu de ti vindo me fosse.

Língua que me cativas, que me enleias

os surtos de ave estranha,

em linhas longas de invisíveis teias,

de que és, há tanto, habilidosa aranha...

Língua-lâmina, língua-labareda,

língua-linfa, coleando, em deslizes de seda...

força inféria ou divina

faz com que o bem e o mal resumas,

língua-cáustico, língua-cocaína,

língua de mel, língua de plumas?...

Amo-te as sugestões gloriosas e funestas,

Amo-te como todas as mulheres

te amam, ó língua-lama, ó língua-resplendor,

pela carne de som que à ideia emprestas

e pelas frases que proferes

nos silêncios de Amor!... (MACHADO, 1978, p. 178-179)

A leitura de "Lépida e leve" em voz alta é bem significativa do que M. H. Abrams chama

de a "quarta dimensão de um poema": "a atividade de enunciar a grande variedade de sons do discurso que constituem as palavras de um poema" (ABRAMS, 2012, p. 2) ( $^{5}$, conceito que

\footnotetext{
${ }^{5}$ As citações e paráfrases de M. H. Abrams, referidas neste ensaio, foram feitas a partir da tradução de fragmentos da conferência "The fourth dimension of a poem", proferida por M. H. Abrams em 2010 na Cornell University, transcritos a seguir na língua original, conforme publicação em livro homônimo: "The fourth dimension - one that is almost totally neglected in discussions of poetry - is the activity of enunciating the great variety of speechsounds that constitutes the words of a poem. It is easy to overlook the fact that a poem, like all art forms, has a physical medium, a material body, which conveys its nonmaterial meanings. That medium is not a written or printed text. The physical medium is the act of utterance by the human voice, as it produces the speech-sounds that convey a poem. We produce those sounds by varying the pressure on the lungs, vibrating or stilling the vocal cords, changing the shape of the throat and mouth, and making wonderfully precise movements of the tongue and lips. It can be said, then, that the physical production of a poem begins next to the heart and ends near the brain. That is one reason that poetry is felt to be the most intimate of the arts, in addition to being the most inclusive and nuanced in expressing what it is to be human. I want to emphasize how important it is to become aware of this fourth, material dimension of a poem. Lifelong and constant habituation in using language has made us largely oblivious to the oral activities that bring a poem into being - the sensations of motion, shape, and touch that we feel, and the oral gestures that we make, in performing such activities; but to be oblivious to these physical sensations and gestures, and simply to look through them to the meanings of the words that they convey, is to disembody a poem. An important advantage of reading a poem aloud is that to do so helps to reembody it, by emphasizing the palpability of its material medium. And that is important, because the oral actions that body forth Revista Graphos, vol. 21, n² 2, 2019| UFPB/PPGL | ISSN 1516-1536
} 
desenvolve em "The fourth dimension of a poem", a partir da leitura das "quatro dimensões" de poemas de W. H. Auden, Emily Dickinson, William Wordsworth, Alfred Tennyson, Ernest Dowson e A. R. Ammons. Recuperando o sentido clássico de elocução, o quarto elemento literário que Aristóteles define, em sua Poética, como o enunciado dos pensamentos por meio das palavras, Abrams também reconhece que um poema, "como todas as formas artísticas, tem um meio físico, um corpo material que transporta seus significados não materiais". Esse meio físico não é apenas o texto escrito ou impresso, mas o próprio ato da enunciação pela voz humana, que traz o poema à vida, à existência, através das sensações de movimento, forma e toque, como também dos gestos orais que realizamos na performance dessas ações. Nesse sentido, ele alinha-se com o pensamento de Octavio Paz, que reconhece que o prazer poético está relacionado, inquestionavelmente, ao ato de respirar e aos movimentos musculares, não só porque a respiração marca o ritmo dos versos mas também porque é a forma de se estabelecer comunhão com o mundo e participar do ritmo universal. Paz afirma que "o ritmo não é som isolado, nem simples significação, nem prazer muscular, mas tudo isso junto, em unidade indissolúvel" (PAZ, 2012, p. 304).

Para Abrams, negligenciar essas sensações e gestos físicos, dando atenção apenas ao significado das palavras, significa "descorporificar" (disembody) um poema. Ler um poema em voz alta tem a grande vantagem de "recorporificá-lo" (reembody it), o que em última instância "pode ter a função de interagir, confirmar e realçar os significados e sentimentos que as palavras transportam". A partir da constatação de que poema é corpo, já que "sua produção física começa próximo ao coração e termina perto do cérebro", ele infere que "a poesia é a mais intimista das artes, além de ser a mais abrangente e variada em expressar o que é humano" (ABRAMS, 2012, p. 3).

O ato de ler "Lépida e leve" em voz alta "recorporifica" o poema, ou talvez seja melhor dizer que a leitura "reencarna" o poema, para seguirmos a sugestão do verso emblemático de Gilka Machado: “A carne de som que à ideia emprestas”. No poema de Gilka, a forma do texto escrito, a combinação sonora, a rede de imagens transportam significados que constroem no leitor efeitos variados de sensações físicas e sentimentos sobre o que significa ser humano, como diz Abrams, assim como também sobre o que significa ser em poesia, e ser em poesia como mulher e poeta. Estamos diante de um metapoema.

the words of a poem, even when they remain below the level of awareness, may serve, in intricate and diverse ways, to interact with, confirm, and enhance the meanings and feelings that the words convey" (ABRAMS, 2012, p. 2-3). 
Esse metapoema de Gilka Machado se estrutura em torno da polissemia de "língua", compreendida em seus três significados: órgão da fala, idioma, discurso. A palavra "língua" figura à qual a voz poética se dirige em interlocução - percorre todo o texto, metendo-se no corpo do poema e tornando-se a síntese (e a alma) da poética gilkiana, acentuadamente erótica. Nesse poema, porém, o erotismo não é apenas tema, mas está no próprio corpo da palavra poética, que seduz o leitor pela exploração de vários sentidos (paladar, tato, visão, audição), como também pelas sugestões poéticas, de que são exemplos as reticências distribuídas ao longo do texto, que acentuam o sentido e a forma insinuantes do poema, e a imagem final, de certa forma paradoxal, da conjugação entre frase e silêncio: "e pelas frases que proferes/ nos silêncios de Amor!...”.

Não apenas a semântica da insinuação, tão prezada pelos poetas simbolistas, chama a atenção no poema. Nele, predominam os substantivos, muitos deles compostos em justaposição, conforme apreciavam os futuristas de Filippo Tommaso Marinetti, que propõe no Manifesto técnico da literatura futurista, de 1912, que "cada substantivo deve ter o seu duplo, isto é, o substantivo deve ser seguido, sem conjunção, do substantivo ao qual está ligado por analogia”, caracterizando, na literatura, a velocidade da vida moderna:

\footnotetext{
Assim como a velocidade aérea multiplicou o nosso conhecimento do mundo, a percepção por analogia torna-se sempre mais natural para o homem. É preciso, por conseguinte, suprimir o como, o qual, o assim, o semelhante a. Melhor ainda, é necessário fundir diretamente o objeto com a imagem que ele evoca, dando a imagem um escorço mediante uma só palavra essencial (MARINETTI in TELLES, 2005, p. 95-6).
}

No poema de Gilka, sobressai o substantivo "língua", combinado com seus duplos análogos, ou com seus contrários, instaurando a fusão e confusão entre bem e mal (sempre inseparáveis na poética gilkiana): por exemplo, a língua-cocaína, que rima audaciosamente com divina, é, ao mesmo tempo, língua de mel, língua de plumas, língua-lâmina, língua-labareda, língua-lama, língua-resplendor, uma pluricombinação de língua em palavras duplas.

Essa estratégia discursiva exige a rapidez na leitura e acentua o dinamismo do poema pela velocidade com que as palavras vão nos capturando e lançando espiralmente para dentro do próprio poema, muito semelhante ao que acontece no anémic-cinéma ${ }^{6}$ (1926) de Marcel Duchamp, em movimento circulatório ad infinitum e hipnótico, até nos aproximarmos do centro do raio do círculo - o polo da espiral ou, no caso dos anagramas de Duchamp, a própria letra $\mathrm{C}$, cuja forma reproduz a imagem da espiral.

\footnotetext{
${ }^{6}$ Disponível em: 〈https://www.youtube.com/watch?v=LpJJsQ3OQ4U〉. Acesso em: 01 set. 2019. Revista Graphos, vol. 21, n 2, 2019 | UFPB/PPGL | ISSN 1516-1536
} 
Em “Lépida e leve", é a letra L que captura nosso olhar hipnoticamente, enquanto o número de repetições da palavra "língua" incita o leitor a marcar com força e intensidade, durante a leitura em voz alta, cada uma das quinze vezes em que a palavra aparece. E, mesmo quando o poema é lido em silêncio, a visualidade da palavra língua "brilha", parecendo suspender-se da página. Nesse sentido, a palavra escrita no poema e ouvida repetidas vezes é colada no leitor eroticamente e também "coleada" no poema como uma serpente pegajosa e sedutora ${ }^{7}$.

De fato, a palavra essencial do poema é língua, constelarmente distribuída na página com seus sentidos vários e combinados, com a profusão sonora da erótica aliteração do fonema linguodental /l/ e a explosão visual de sintagmas nominais, compondo versos harmônicos na combinação de sons simultâneos, tal como conceituou Mário de Andrade no fragmento 36 (ANDRADE, 2005, p. 68-9) de seu "Prefácio interessantíssimo" ao livro Pauliceia desvairada. O resultado é uma espécie de conjunção verbal, visual e sonora em performance, que se aproxima do que Marjorie Perloff, a partir do conceito de "momento futurista" de Renato Poggioli, discute como "legado futurista" no livro O momento futurista: avant-garde, avanteguerre e a linguagem da ruptura, publicado originalmente em 1986 e traduzido no Brasil em 1993. Sobre momento futurista diz Perloff:

É o momento em que a colagem, a mise en question da pintura como uma
representação da "realidade", faz seu primeiro aparecimento, quando o manifesto
político é percebido esteticamente, da mesma forma que o objeto estético - pintura,
poema, drama - é politizado. Os mídias - verbal, visual, musical - são cada vez mais
usados em conjunção: o futurismo é a época da arte da performance, da chamada
poesia do som e do livro do artista (PERLOFF, 1993, p. 83).

Gilka Machado é uma poeta do momento futurista (não do movimento futurista). Gilka é uma poeta moderna nesse poema-língua, pela visualidade e sonoridade representativas de certa poética da modernidade; pelas colagens simultâneas e sucessivas da palavra língua, dínamo do seu poema; pelo dinamismo e a velocidade defendidos pelos futuristas sem a violência protofascista de Marinetti; pelas paroles in libertà de um "divino pecado" e de rejeição a um "tolo recato"; pela imaginação sem fios de um "réptil que voa"; pela palavra que é a própria liberdade e que, no caso de Gilka, será a própria reação, revolução, energia de resistência - a língua da poesia. Gilka é poeta moderna nesse seu poema-língua que, com imagens de som,

\footnotetext{
${ }^{7}$ Convém registrar aqui o significado de "colear", verbo empregado pela poeta: mover-se como serpente. A paronomásia entre colar e colear nos parece evidente no poema e aponta para a conjugação de sentidos sonoros e semânticos, materiais e não-materiais, comum na poesia de Gilka Machado.
}

Revista Graphos, vol. 21, $\mathrm{n}^{\circ}$ 2, 2019 | UFPB/PPGL | ISSN 1516-1536 
cor, dança e movimento cinético, atravessa a fronteira entre tradição e renovação, entre ruptura e reconstrução, entre passado e futuro.

Gilka Machado é poeta futurista (não de Marinetti). Talvez Gilka seja a poeta futurista de Valentine de Saint-Point. O Manifesto da mulher futurista, de 1912, escrito por Saint-Point em "resposta a F. T. Marinetti” por seu "desprezo às mulheres”, começa com uma explosão: “A humanidade é medíocre. A maioria das mulheres não é nem superior nem inferior à maioria dos

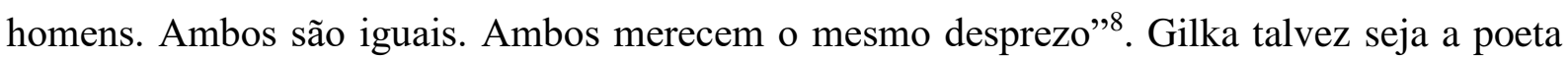
futurista daquela mesma Saint-Point que, no Manifesto futurista da luxúria, de 1913, despreza a mulher vestida pela moral cristã com os "sinistros trapos românticos" e registra: "A luxúria é uma força",

O futurismo da performance da visualidade e sonoridade em conjunção, representativa da modernidade poética de Gilka Machado, como vimos apontando, fará os olhos do leitor, no entanto, se lançarem a um passado, que ela não recusa, mas renova e reapresenta. Os olhos do leitor de "Lépida e leve" se dirigirão à estrofe, abaixo transcrita, em que se combinam versos melódicos, sintaticamente escorreitos (ainda segundo a definição de Mário de Andrade), devidamente representativos da "retomada" de formas tradicionais de expressão na poética moderna de "renovação" de Gilka. Nesta estrofe, o leitor encontra o eixo da hélice flexuosa e tortuosa do poema e faz uma viagem para dentro do corpo e da alma do próprio texto e da própria língua, conduzido hipnoticamente (insistimos) do campo do visual retiniano para o interior do poema, participando com a poeta do ato de autoconsciência poética:

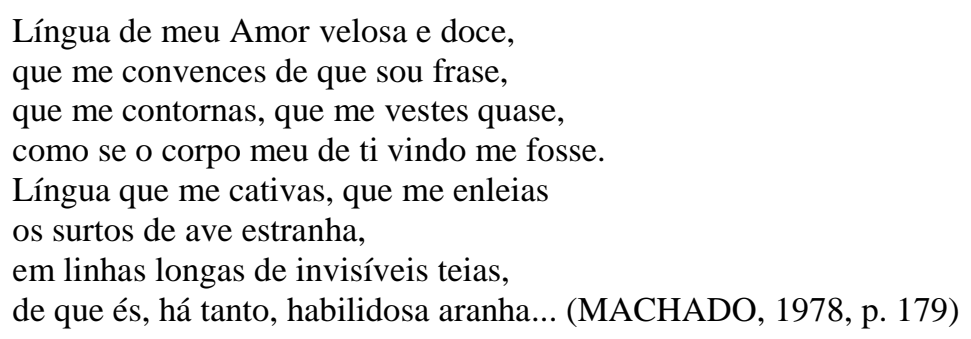

No primeiro verso (um decassílabo heroico, convém destacar), está a palavra Amor, sublimada pela letra maiúscula e acentuada pelo icto. Também com essa palavra Gilka encerra o poema, sempre grafada em maiúscula, bem ao gosto dos simbolistas. Nesse mesmo verso, a produção física do poema decorre da sinestesia entre tato e paladar ("velosa e doce"), dois

\footnotetext{
${ }^{8}$ Disponível em: <https://www.wdl.org/pt/item/20029/\#institution=university-library-of-padua $>$. Acesso em: 01 set. 2019.

${ }^{9}$ Disponível em: <https://www.wdl.org/pt/item/20035/\#institution=university-library-of-padua $>$. Acesso em: 01 set. 2019.
} 
sentidos que talvez melhor transportem a carga erótica e semântica da língua - a língua da boca que fala; a língua da boca que lambe o corpo e sente seu gosto doce e o toque aveludado. A força luxuriante do texto é indiscutível, poderia ter dito Saint-Point.

Nessa mistura de sentidos materiais e significados não materiais, Gilka não mais dissocia prazer sexual de prazer de escrita, que estão intimamente associados no fazer poético da mulher, cuja voz é frase. No corpo escrito do poema, é exatamente ela, a língua (a língua amada ou a língua sobre o amor, pela duplicidade provocada pelo genitivo "de meu Amor"), que convence o eu poético a ser frase. Frase que, como tal, é um enunciado de sentido completo, não um fragmento de outro enunciado; e, ao mesmo tempo, é ela (a voz que fala no poema, a frase construída completa no poema) a própria enunciação, contornada pelo traço da língua que toca o corpo, e da língua que fala e escreve o poema. Frase que é a voz da poeta-mulher que se faz no texto e se faz texto: a mulher-frase inteira, com sentido completo, próprio e autônomo, como uma aranha tecedeira de palavras em suas teias.

Consciente da intensa carga reflexiva da poesia tanto como espaço de apreensão da matéria e do material poéticos como também de discussão do papel da mulher como autora, Gilka consegue, assim, contestar os dois parâmetros que sempre guiaram o gênero lírico: a lírica como intensa expressão da experiência de um autor/uma autora, ou a lírica como representação ficcional do ato discursivo de uma persona. Borrando esses modelos que limitam e ignoram o que há de mais significativo e excitante nos poemas líricos - sua tensão permanente entre o fora e o dentro -, o poema nos coloca diante da mulher-frase de corpo e alma, nua e livre com sua língua que se faz corpo a escrever nas "invisíveis teias" da poesia e corpo escrito nas "linhas longas" do poema, em que se enredam e dançam Amor, Língua e Mulher, conjugados em uma performance rítmica, corporal e visual, "como se o corpo meu de ti vindo me fosse". A lírica e muito menos a lírica gilkiana - não se submete a limites que a enformam.

Desse modo, o lugar da poesia de Gilka - de altíssima e indiscutível carga erótica - não pode ser compreendido apenas a partir da tematização. Ao meter a língua no locus poeticus coração e cérebro da linguagem poética - do canto erótico, Gilka Machado abre sua poética à reflexão sobre a consciência e autoconsciência eróticas da poesia e sobre o fazer poético da poeta-mulher que, na carne e no corpo do poema, encontra sua voz e - talvez - o único lugar que permite a ela estar nua, livre e plena de prazer, como a língua da poesia. 


\section{Referências}

ABRAMS, M. H. The fourth dimension of a poem and other essays. New York; London: W.W. Norton \& Company, 2012.

ANDRADE, Carlos Drummond de. Gilka, a antecessora. Jornal do Brasil, RJ, p.7, 18 dez. 1980.

ANDRADE, Mário de. Poesias completas. Belo Horizonte: Editora Itatiaia, 2005.

ARISTÓTELES. Poética. Trad. Eudoro de Souza. $3^{\text {a }}$. ed. São Paulo, Ars Poética, 1993.

ATHAYDE, Tristão de. Contribuição à história do modernismo: o pré-modernismo. Vol. I. Rio de Janeiro: José Olympio, 1939.

BANDEIRA, Manuel. Apresentação da poesia brasileira. $3^{\text {a }}$. ed. Rio de Janeiro: Casa do Estudante do Brasil, 1957.

BAUDELAIRE, Charles. As flores do mal. Trad. Ivan Junqueira. Rio de Janeiro: Nova Fronteira, 1985.

CANDIDO, Antonio. Literatura e sociedade: estudos de teoria e história literária. $8^{\mathrm{a}}$. ed. São Paulo: T. A. Queiroz Editor, 2000.

COELHO, Nelly Novaes. Dicionário crítico de escritoras brasileiras (1711-2001). São Paulo: Escrituras, 2002.

DUCHAMP, Marcel. Anémic-cinéma. Disponível em:

<https://www.youtube.com/watch?v=LpJJsQ3OQ4U>. Acesso em: 01 set. 2019.

MACHADO, Gilka. Dados autobiográficos de Gilka Machado. In: Poesias completas. Rio de Janeiro: Cátedra; Brasília: INL/MEC, 1978. p. IX-XI.

MACHADO, Gilka. Poesias completas. Rio de Janeiro: Cátedra; Brasília: INL/MEC, 1978.

MARINETTI, Filippo Tommaso. Manifesto técnico da literatura futurista. In: TELLES, Gilberto Mendonça. Vanguarda europeia e modernismo brasileiro: apresentação dos principais poemas, manifestos, prefácios e conferências vanguardistas de 1857 a 1972. Petrópolis, RJ: Vozes, 1997. p. 95-99.

PAZ, Octavio. O arco e a lira. Trad. Ari Roitman e Paulina Wacht. São Paulo: Cosac Naify, 2012.

PERLOFF, Marjorie. O momento futurista: avant-garde, avant-guerre e a linguagem da ruptura. Trad. Sebastião Uchoa Leite. São Paulo: Editora da Universidade de São Paulo, 1993. [Texto \& Arte 4].

PY, Fernando. Prefácio. In: MACHADO, Gilka. Poesias completas. Rio de Janeiro: Cátedra; Brasília: INL/MEC, 1978. p. XIX-XXVIII.

SADLIER, Darlene J. O locus eroticus na poesia de Gilka Machado. Revista Brasileira. Fase VIII, Ano II, nº. 75, p. 237-244, abril-maio-junho 2013. 
SAINT-POINT, Valentine de. Manifesto della donna futurista: risposta a F.T. Marinetti. Disponível em: <https://www.wdl.org/pt/item/20029/\#institution=university-library-ofpadua>. Acesso em: 01 set. 2019.

Manifesto futurista della lussuria. Disponível em:

$<$ https://www.wdl.org/pt/item/20035/\#institution=university-library-of-padua $>$. Acesso em: 01 set. 2019.

SILVA, Domingos Carvalho da. Vozes femininas da poesia brasileira. São Paulo: Conselho Estadual de Cultura, 1959.

SOARES, Angélica. A paixão emancipatória: vozes femininas da liberação do erotismo na poesia brasileira. Rio de Janeiro: Difel, 1999.

VALÉRY, Paul. Questões de poesia. In: Variedades. Trad. Maíza Martins de Siqueira. São Paulo: Iluminuras, 1991. p. 177-186.

Recebido em: 01/09/2019

Aceito para publicação em: 31/10/2019 